\title{
Meta
}

Journal des traducteurs

Translators' Journal

\section{"The translations that never were": why the works of the Brazilian writer Monteiro Lobato were not translated into English, though many were into Spanish}

\section{John Milton}

Volume 60, numéro 2, août 2015

$60^{\mathrm{e}}$ anniversaire. Les horizons de la traduction : retour vers le futur

$60^{\text {th }}$ Anniversary. Translation's Horizons: Back to the Future

60mo aniversario. Los horizontes de la traducción: regreso al futuro

URI : https://id.erudit.org/iderudit/1032908ar

DOI : https://doi.org/10.7202/1032908ar

Aller au sommaire du numéro

Éditeur(s)

Les Presses de l’Université de Montréal

ISSN

0026-0452 (imprimé)

1492-1421 (numérique)

Découvrir la revue

Citer ce document

Milton, J. (2015). "The translations that never were": why the works of the Brazilian writer Monteiro Lobato were not translated into English, though many were into Spanish. Meta, 60(2), 357-357.

https://doi.org/10.7202/1032908ar 


\title{
"The translations that never were": why the works of the Brazilian writer Monteiro Lobato were not translated into English, though many were into Spanish
}

\author{
John Milton \\ Universidade de São Paulo, São Paulo, Brazil \\ jmilton@usp.br
}

This paper initiates the second part of a project on the translations and adaptations of José Bento Monteiro Lobato (1882-1948), publisher, journalist, writer of fiction, children's books, and treatises, who wished to bring a more progressive mentality to Brazil. Lobato is one of the best-known figures in Brazilian literature and a key figure in the development of the Brazilian publishing industry.

In "The Resistant Translations of Monteiro Lobato," published in Translation and Resistance, I examined Lobato's critiques of the populist dictatorship of Getúlio Vargas (1930-1945) through a technique of retelling of children's works such as Peter Pan, criticizing the situation of Brazil under the dictatorship of Vargas.

This study moves to the translations of Lobato's work into other languages. Lobato, a great admirer of North American industry and efficiency - he was the Brazilian Commercial Attaché in New York from 1928 to 1930 - greatly wished his work to be translated into English. However, his futuristic O Presidente Negro (The Black President) (1926), which imagined the presidential elections of 2028, where the black candidate, Jim Roy, is elected but then manipulated by white forces who attempt to eugenically control the black population. But Lobato failed to find a publisher, and only a few of his short stories were published in the US. He found greater success in Argentina, where he lived from 1946 to 1947. His most important works for children were published in Buenos Aires and other South American countries. The President of Argentina, Cristina Kirchner, was an avid reader of Lobato as a child.

John Milton, born Birmingham, UK, 1956, is Titular Professor, University of São Paulo, Brazil, teaching English Literature at undergraduate level and Translation Studies at M.A. and Ph.D. level, and is the Coordinator of the M.A. and Ph.D. Postgraduate Programme in Translation Studies, which started in August 2012. He is also a member of the Ph.D. team on the Intercultural Studies Group at Universitat Rovira i Virgili in Tarragona headed by Anthony Pym. His main interest is in the theory, history, sociology and politics of translation and has published several books in Brazil and edited (with Paul Bandia) Agents of Translation. Amsterdam: John Benjamins, 2009. 